\title{
Benzyladenine as A Chemical Thinner for 'McIntosh' Apples. II. Effects of Benzyladenine, Bourse Shoot Tip Removal, and Leaf Number on Fruit Retention
}

\author{
Rongcai Yuan ${ }^{1}$ and Duane W. Greene ${ }^{2}$ \\ Department of Plant and Soil Sciences, University of Massachusetts, Amherst, MA 01003
}

\begin{abstract}
AdDitional INDEX wORDS. cytokinin, BA, fruit thinning, fruit abscission, fruit development, fruit quality, Malus sylvestris var. domestica

Abstract. Experiments were conducted to evaluate the effects of BA, removal of bourse shoot tips including only folded leaves and growing point, and different numbers of leaves per fruit on fruit retention and fruit development in 'MoreSpur McIntosh'/Malling 7 (M.7) apple trees [Malus sylvestris (L.) Mill var. domestica (Borkh.) Mansf.]. Removal of the bourse shoot tip increased fruit retention, whereas BA thinned fruit regardless of whether shoot tips were removed or not. There was no interaction between BA application and shoot tipping. BA thinned fruit only when one leaf per fruit was on a girdled small fruiting branch, but not when leaf number per fruit was two or greater. Fruit weight and soluble solids concentration increased dramatically with increasing leaf number per fruit. BA reduced fruit growth rate when $<16$ leaves per fruit were present on the girdled branches between 3 and 7 days after treatment, but it did not affect fruit growth rate when 32 leaves per fruit were on the girdled branches. Increasing leaf number also increased viable seed number per fruit while decreasing the number of aborted seeds, but it had no effect on the number of total seeds per fruit. BA reduced the number of viable seeds per fruit only when the number of leaves per fruit was less than four. Results suggest that BA thins apple fruit mainly by reducing carbohydrates available to developing fruitlets. Chemical name used: N-(phenylmethyl)-1H-purine-6-amine [benzyladenine (BA)].
\end{abstract}

Fruit thinning at an early stage of fruit development improves fruit size, and reduces biennial bearing in apples [Malus sylvestris (L.) Mill var.domestica (Borkh.) Mansf.] (Williams and Edgerton, 1981). BA is an effective chemical thinner for many apple cultivars (Bound et al., 1991; Elfving and Cline, 1993; Greene, 1993; Greene et al., 1990; Wismer et al., 1995). However, little is known about its mode of action as a chemical thinner. BA effectively thins fruit when applied at the $10 \mathrm{~mm}$ stage of fruit development at 50 to $100 \mathrm{mg} \cdot \mathrm{L}^{-1}$, and it thins more effectively when applied to leaves than fruit (Greene et al., 1992).

Carbohydrates are essential for fruit set and subsequent growth. Apple fruit abscission after fertilization and during 'June drop' has been attributed to competition for essential metabolites, including photosynthates, among individual fruitlets and between fruitlets and vegetative shoots (Abbott, 1960; Knight, 1980; Quinlan and Preston, 1971). Shoot tip removal reduces fruit abscission and increases yield (Quinlan and Preston, 1971).

Removal of spur and shoot leaves causes extensive apple fruit abscission (Arthey and Wilkinson, 1964; Llewelyn, 1963, 1968; Ferree and Palmer, 1982; Proctor and Palmer, 1991). Fruit set is reduced by a reduction in spur leaf area, and the combination of ringing the spur and removal of all spur leaves causes complete fruit loss (Ferree and Palmer, 1982). A minimum of two leaves per spur are required for normal apple fruit set (Heinicke, 1917). Therefore, the objective of this study was to evaluate the effects of removal of bourse shoot tip, different leaf numbers or area, and BA on fruit abscission and fruit development in apples.

\footnotetext{
Received for publication 19 Apr. 1999. Accepted for publication 26 Oct. 1999. ${ }^{1}$ Former Graduate Research Assistant. Current Address: University of Florida, Citrus Research and Education Center, 700 Experiment Station Road, Lake Alfred, FL 33850-2299. The cost of publishing this paper was defrayed in part by the payment of page charges. Under postal regulations, this paper therefore must be hereby marked advertisement solely to indicate this fact. ${ }^{2}$ Professor.
}

\section{Materials and Methods}

All trees used were mature, bearing 'More-Spur McIntosh'/ Malling 7 (M.7) growing at the University of Massachusetts Horticultural Research Center, Belchertown, Mass.

BOURSE SHOOT TIP REMOVAL (EXPT. 1). Four uniform limbs, 12 to $15 \mathrm{~cm}$ in circumference, were selected, measured, and tagged on each of eight mature 'More-Spur McIntosh'/M.7 apple trees in 1996. A randomized complete block design was used. BA at 100 $\mathrm{mg} \cdot \mathrm{L}^{-1}$ and removal of bourse shoot tips were applied alone and in combination on three of the limbs on 30 May 1996, at the 10 $\mathrm{mm}$ stage of fruit development. The portion of the bourse shoot tips that were removed included only folded leaves and growing point. The fourth limb was nontreated and served as a control. Each tree was a replication. Fruit on each tagged limb were counted on 30 May 1996 just before treatments were applied and on 8 July 1996 at the end of 'June drop'. Fruit weight, color, flesh firmness, and soluble solids concentration were determined at commercial harvest. Fruit color was estimated visually to the nearest $10 \%$. Flesh firmness was determined using an Effegi penetrometer (Alfonsine, Italy). Soluble solids concentration was measured using hand-held refractometer (Fisher Scientific, Pittsburgh, Pa.).

SPUR LEAF AREA IN 1996 (EXPT. 2). Sixty small fruiting branches of similar vigor, $\approx 0.6 \mathrm{~cm}$ in diameter, were selected and tagged in five mature 'More-Spur McIntosh'/M.7 trees. From each small branch a $5 \mathrm{~mm}$ wide strip of phloem, cambial tissue, and connected bark was removed on 30 May 1996. The girdle was monitored periodically for cambial growth and was scraped to prevent phloem reconnection until the end of 'June drop'. A randomized complete block design with 15 replications was used with three replications on each tree. All fruit, but one, were removed, and the number of spur leaves was then adjusted to 25 or 50 per girdled small branch either nontreated or receiving BA 
at $100 \mathrm{mg} \cdot \mathrm{L}^{-1}$. Treatments were applied on 30 May 1996 at the 10 $\mathrm{mm}$ stage of fruit development. New shoots were removed on girdled small branches before the end of 'June drop'. Fruit remaining on each tagged branch were counted and fruit diameter was measured after 'June drop'. Fruit weight, flesh firmness, soluble solids concentration, and seed number per fruit were determined as described in Expt. 1 at commercial harvest.

SPUR LEAF AREA IN 1997 (EXPT. 3). One hundred and ninety-two small fruiting branches of similar vigor, $\approx 0.5 \mathrm{~cm}$ in diameter, were selected and tagged in eight mature 'More-Spur McIntosh' trees. From each small branch a $5 \mathrm{~mm}$ wide strip of phloem, cambial tissue, and connected bark was removed, and the exposed ring was covered immediately with plastic tape on 6 June 1997. The girdle was monitored periodically for cambial growth and was scraped to prevent phloem reconnection until the end of 'June drop'. A randomized complete block design with 16 replications was used with two replications on each tree. All fruit, but one, were removed, and the number of spur leaves was then adjusted to $1,2,4,8,16$ or 32 per girdled small branch either nontreated or treated with BA at $100 \mathrm{mg} \cdot \mathrm{L}^{-1}$. Treatments were applied on 6 June 1997, at the $10 \mathrm{~mm}$ stage of fruit development. New shoots were removed on girdled small branches before the end of 'June drop'. Fruit remaining on each tagged branch and fruit diameter were monitored every 2 or $3 \mathrm{~d}$ after treatment. Solar radiation and air temperature were recorded using a Campbell Scientific Weather
Station equipped with a datalogger (CR10X; Campbell Scientific, Inc., Logan, Utah). The average of the maximum air temperature and solar radiation over the 2 to $3 \mathrm{~d}$ period between fruit diameter measurements was calculated to correlate to fruit growth. Leaf area was measured at commercial harvest of fruit using a leaf area meter (LI-3000; LI-COR, Lincoln, Nebr.). Fruit weight, soluble solids concentration, and seed number per fruit were determined as described above at commercial harvest.

Statistical analyses. Statistical analyses included analysis of variance, Duncan's multiple range test, and orthogonal polynomial comparisons. Where interaction of main effects were significant, sums of squares were partitioned into the sums of squares of one main effect nested within each level of the other main effect involved in the interaction. Statistical Analysis Systems Software for PC (SAS Inst., Cary, N.C.) was used for data analyses.

\section{Results}

BOURSE SHOOT TIP REMOVAL (EXPT. 1). Overall, removal of the bourse shoot tip at the $10 \mathrm{~mm}$ stage of fruit development significantly increased fruit retention regardless of BA treatment (Table 1). There was no response to removal of bourse shoot tips in fruit weight, red color, flesh firmness, and soluble solids concentration.

Table 1. Effects of BA and bourse shoot tip removal on fruit retention and fruit quality at harvest of 'More-Spur McIntosh' apples (1996). ${ }^{\mathrm{Z}}$

\begin{tabular}{|c|c|c|c|c|c|c|c|}
\hline \multicolumn{2}{|c|}{ Treatment $^{y}$} & \multicolumn{2}{|c|}{$\begin{array}{c}\text { Fruit/cm } \\
\text { LCSA }^{\mathrm{x}}\end{array}$} & \multirow{2}{*}{$\begin{array}{c}\text { Fruit } \\
\text { wt } \\
(\mathrm{g})\end{array}$} & \multirow{2}{*}{$\begin{array}{l}\text { Red } \\
\text { color } \\
(\%)\end{array}$} & \multirow{2}{*}{$\begin{array}{c}\text { Flesh } \\
\text { firmness } \\
\left(\mathrm{N} \cdot \mathrm{cm}^{-2}\right)\end{array}$} & \multirow{2}{*}{$\begin{array}{c}\text { Soluble } \\
\text { solids } \\
\text { concn }(\%)\end{array}$} \\
\hline Shoots & BA & 30 May & 8 July & & & & \\
\hline$+{ }^{\mathrm{W}}$ & - & 17.1 & 6.2 & 159.6 & 45.0 & 68.3 & 11.6 \\
\hline- & - & 16.8 & 6.9 & 150.2 & 40.0 & 69.7 & 11.6 \\
\hline+ & + & 18.0 & 2.4 & 188.0 & 29.0 & 69.3 & 11.9 \\
\hline- & + & 19.1 & 3.8 & 183.6 & 31.0 & 68.3 & 11.6 \\
\hline \multicolumn{8}{|c|}{ Significance } \\
\hline BA & & NS & $* *$ & $* *$ & $* *$ & NS & NS \\
\hline Sho & & NS & $*$ & NS & NS & NS & NS \\
\hline $\mathrm{BA}$ & & NS & NS & NS & NS & NS & NS \\
\hline
\end{tabular}

${ }^{\mathrm{z}}$ Means of eight observations.

yBA at $100 \mathrm{mg} \cdot \mathrm{L}^{-1}$ and tipping were applied on 30 May 1996 at the $10-\mathrm{mm}$ stage of fruit development.

${ }^{x}$ LCSA $=$ limb cross-sectional area.

${ }^{\text {w}}$ With the presence of shoot tip.

Ns, *,** Nonsignificant or significant at $P<0.05$ or 0.01 , respectively.

Table 2. Effects of BA and different leaf number per fruit on fruit retention and quality at harvest of 'More-Spur McIntosh' apples (1996). ${ }^{\mathrm{X}}$

\begin{tabular}{|c|c|c|c|c|c|c|c|c|c|c|}
\hline \multirow{2}{*}{$\begin{array}{l}\mathrm{BA}^{\mathrm{y}} \\
\left(\mathrm{mg} \cdot \mathrm{L}^{-1}\right)\end{array}$} & \multirow{2}{*}{$\begin{array}{l}\text { Leaf } \\
\text { no. }\end{array}$} & \multicolumn{2}{|c|}{ Fruit no. } & \multirow{2}{*}{$\begin{array}{c}\text { Fruit } \\
\text { abscission } \\
\text { rate }(\%)\end{array}$} & \multirow{2}{*}{$\begin{array}{c}\text { Fruit } \\
\text { wt } \\
(\mathrm{g})\end{array}$} & \multirow{2}{*}{$\begin{array}{c}\text { Flesh } \\
\text { firmness } \\
\left(\mathrm{N} \cdot \mathrm{cm}^{-2}\right)\end{array}$} & \multirow{2}{*}{$\begin{array}{c}\text { Soluble } \\
\text { solids } \\
\text { concn }(\%)\end{array}$} & \multicolumn{3}{|c|}{ Seed no. } \\
\hline & & Initial & $\overline{\text { Final }}$ & & & & & Viable & Aborted & Total \\
\hline \multirow[t]{2}{*}{0} & 25 & 1.0 & 1.0 & 0 & 135.4 & 81.2 & 12.3 & 8.3 & 2.3 & 10.6 \\
\hline & 50 & 1.0 & 1.0 & 0 & 151.3 & 82.6 & 11.7 & 8.7 & 2.0 & 10.7 \\
\hline \multirow[t]{2}{*}{100} & 25 & 1.0 & 1.0 & 0 & 154.2 & 83.5 & 11.6 & 9.1 & 2.4 & 11.5 \\
\hline & 50 & 1.0 & 1.0 & 0 & 170.5 & 80.3 & 12.5 & 8.9 & 2.6 & 11.5 \\
\hline \multicolumn{11}{|l|}{ Significance } \\
\hline BA & & NS & NS & NS & $* *$ & NS & NS & NS & NS & NS \\
\hline Leaves & & NS & NS & NS & $* *$ & NS & NS & NS & NS & NS \\
\hline BA $\times$ leaves & & NS & NS & NS & NS & NS & NS & NS & NS & NS \\
\hline
\end{tabular}

${ }^{\mathrm{z}}$ Mean of 15 observations.

yTreatments were applied on 30 May 1996 at the 10-mm stage of fruit development.

Ns, ${ }^{* *}$ Nonsignificant or significant at $P<0.01$, respectively. 
Table 3. Effects of BA and different leaf number per fruit on fruit retention of 'More-Spur McIntosh' apples (1997). ${ }^{\mathrm{z}}$

\begin{tabular}{|c|c|c|c|c|c|}
\hline \multirow{2}{*}{$\begin{array}{l}\mathrm{BA}^{\mathrm{y}} \\
\left(\mathrm{mg} \cdot \mathrm{L}^{-1}\right)\end{array}$} & \multirow{2}{*}{$\begin{array}{l}\text { Leaf } \\
\text { no. }^{y}\end{array}$} & \multirow{2}{*}{$\begin{array}{c}\text { Leaf } \\
\text { area } \\
\left(\mathrm{cm}^{2}\right)\end{array}$} & \multicolumn{2}{|c|}{ Fruit no. } & \multirow{2}{*}{$\begin{array}{c}\text { Fruit } \\
\text { abscission } \\
\operatorname{rate}(\%)\end{array}$} \\
\hline & & & Initial & Final & \\
\hline \multirow[t]{6}{*}{0} & 1 & 31.5 & 1.0 & 0.75 & 25.0 \\
\hline & 2 & 56.8 & 1.0 & 1.0 & 0.0 \\
\hline & 4 & 112.8 & 1.0 & 1.0 & 0.0 \\
\hline & 8 & 210.0 & 1.0 & 1.0 & 0.0 \\
\hline & 16 & 412.4 & 1.0 & 1.0 & 0.0 \\
\hline & 32 & 874.9 & 1.0 & 1.0 & 0.0 \\
\hline \multirow[t]{6}{*}{100} & 1 & 31.5 & 1.0 & 0.125 & 87.5 \\
\hline & 2 & 57.1 & 1.0 & 1.0 & 0.0 \\
\hline & 4 & 121.1 & 1.0 & 1.0 & 0.0 \\
\hline & 8 & 208.5 & 1.0 & 1.0 & 0.0 \\
\hline & 16 & 412.1 & 1.0 & 1.0 & 0.0 \\
\hline & 32 & 886.2 & 1.0 & 1.0 & 0.0 \\
\hline \multicolumn{6}{|c|}{ Significance } \\
\hline $\mathrm{BA}$ & & NS & & & $* * *$ \\
\hline Leaves & & $\mathrm{L}^{* * * *} \mathrm{Q}^{* * * *}$ & & & $* * *$ \\
\hline $\mathrm{BA} \times$ lea & & & & & $* * *$ \\
\hline BA : 1 & & & & & $* * *$ \\
\hline $\mathrm{BA}: 1$ & & & & & NS \\
\hline $\mathrm{BA}: 1$ & & & & & NS \\
\hline
\end{tabular}

${ }^{\mathrm{z}}$ Mean of 16 observations.

yTreatments were applied on 6 June 1997 at the $10 \mathrm{~mm}$ stage of fruit development.

Ns, ${ }^{* * *}$ Nonsignificant or significant at $P<0.001$, respectively.

BA effectively thinned 'More-Spur McIntosh' apples regardless of whether or not bourse shoot tips were removed (Table 1). Fruit weight increased $\approx 20 \%$ by BA application, whereas red color was decreased. BA did not influence flesh firmness and soluble solids concentration.

SPUR LEAF AREA IN 1996 (EXPT. 2). BA treatment had no influence on fruit abscission when leaf number per fruit was either 25 or 50 (Table 2). Fruit weight was increased both by BA and by

Table 4. Effects of BA and different leaf number per fruit on fruit quality at harvest of 'More-Spur McIntosh' apples (1997) ${ }^{\mathrm{Z}}$

\begin{tabular}{|c|c|c|c|c|c|c|}
\hline \multirow{2}{*}{$\begin{array}{l}\text { BA } \\
\left(\mathrm{mg} \cdot \mathrm{L}^{-1}\right)^{\mathrm{y}}\end{array}$} & \multirow{2}{*}{$\begin{array}{l}\text { Leaf } \\
\text { no. }^{y}\end{array}$} & \multirow{2}{*}{$\begin{array}{c}\text { Soluble } \\
\text { solids } \\
\text { concn }(\%)\end{array}$} & \multirow{2}{*}{$\begin{array}{c}\text { Fruit } \\
\mathrm{wt} \\
(\mathrm{g})\end{array}$} & \multicolumn{3}{|c|}{ Seed no. } \\
\hline & & & & Viable & Aborted & Total \\
\hline \multirow[t]{6}{*}{0} & 1 & 8.2 & 24.2 & 5.8 & 6.2 & 12.0 \\
\hline & 2 & 9.2 & 58.5 & 9.7 & 1.8 & 11.5 \\
\hline & 4 & 9.6 & 92.6 & 11.5 & 0.8 & 12.3 \\
\hline & 8 & 10.7 & 118.1 & 10.2 & 1.0 & 11.2 \\
\hline & 16 & 11.4 & 130.0 & 10.2 & 0.9 & 11.0 \\
\hline & 32 & 11.9 & 135.6 & 9.9 & 0.9 & 10.8 \\
\hline \multirow[t]{6}{*}{100} & 1 & 8.8 & 32.0 & 1.5 & 9.0 & 10.5 \\
\hline & 2 & 9.2 & 66.7 & 7.9 & 3.5 & 11.4 \\
\hline & 4 & 9.8 & 97.2 & 8.8 & 1.9 & 10.7 \\
\hline & 8 & 10.6 & 117.6 & 9.1 & 1.2 & 10.3 \\
\hline & 16 & 11.5 & 129.1 & 10.0 & 0.7 & 10.7 \\
\hline & 32 & 12.5 & 147.8 & 9.9 & 0.9 & 10.8 \\
\hline \multicolumn{7}{|l|}{ Significance } \\
\hline BA & & NS & NS & $*$ & NS & NS \\
\hline Leaves & & $\mathrm{L}^{* * *} \mathrm{Q}^{\mathrm{NS}}$ & $\mathrm{L}^{* * * *} \mathrm{Q}^{* * *}$ & $\mathrm{~L}^{* * * *} \mathrm{Q}^{* *}$ & $\mathrm{~L}^{* * * *} \mathrm{Q}^{* * *}$ & NS \\
\hline BA $\times$ leaves & & NS & NS & $*$ & NS & NS \\
\hline BA : leaves 1 & & & & $*$ & & \\
\hline BA : leaves 2 & & & & $*$ & & \\
\hline BA : leaves 4 & & & & $*$ & & \\
\hline BA : leaves 8 & & & & NS & & \\
\hline
\end{tabular}

${ }^{\mathrm{z}}$ Mean of 16 observations.

yTreatments were applied on 6 June 1997 at the 10-mm stage of fruit development.

Ns,*,**,**** Nonsignificant or significant at $P<0.05,0.01$, or 0.001 , respectively. 


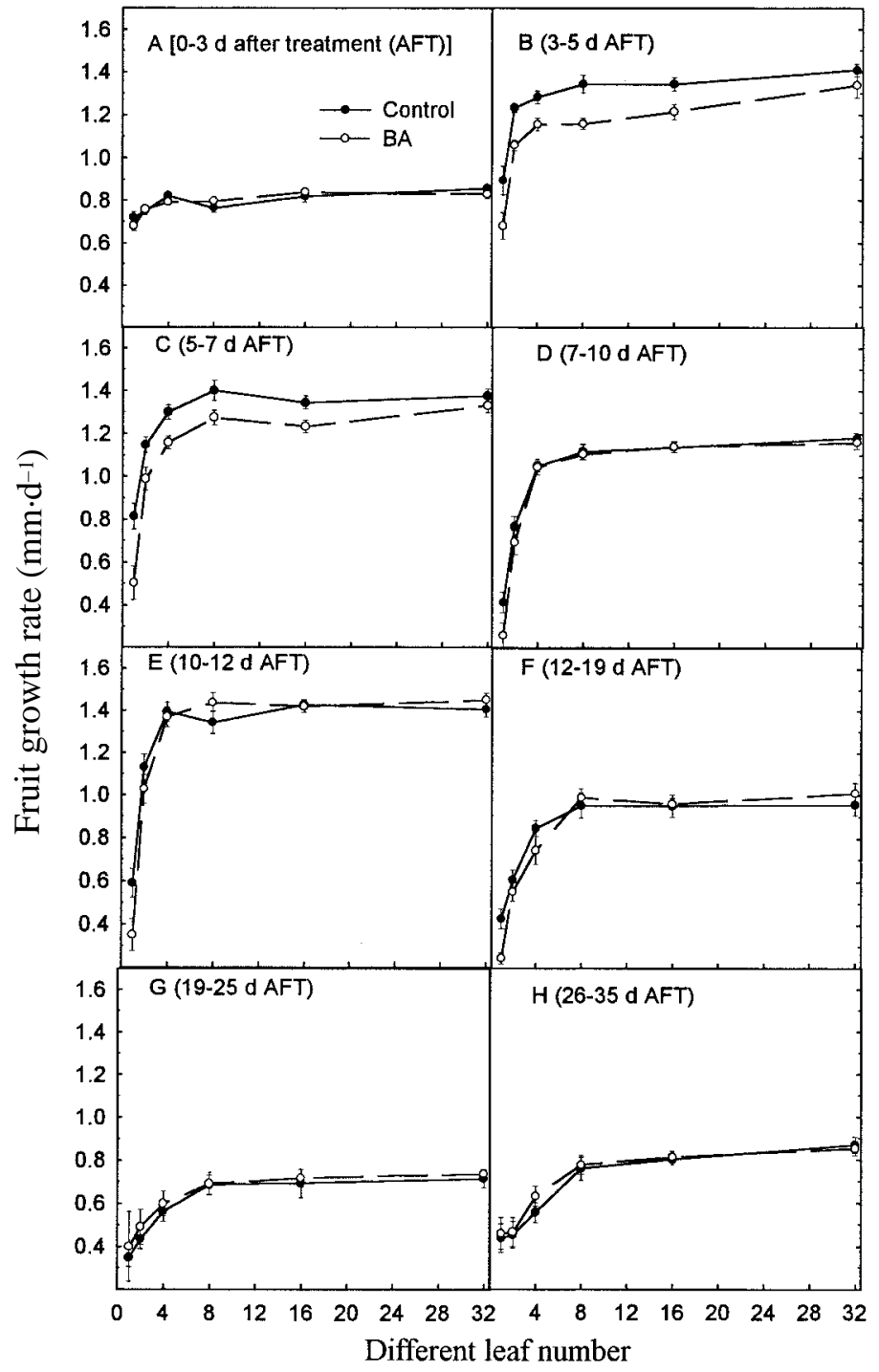

Fig. 1. Effects of BA and different leaf number per fruit on fruit growth rate of 'More-Spur McIntosh' apples. Legend in A applies to all figures. Data are means \pm SE $(n=16)$

increasing leaf number to 50 per fruit. However, there was no significant effect of BA or leaf number on flesh firmness, soluble solids concentration, and viable, aborted, and total seed number.

SPUR LEAF AREA IN 1997 (EXPT. 3). Leaf area increased with increasing leaf number per fruit (Table 3). Overall, fruit abscission decreased with increasing leaf number per fruit, but BA increased fruit abscission. There was a significant interaction between BA and leaf number per fruit in fruit abscission. BA increased fruit abscission only when there was just one leaf per fruit on the girdled small fruiting branch, but not when leaf number was two or greater.

Overall, the number of viable seeds per fruit at commercial harvest was reduced by BA application but increased with increasing leaf number per fruit (Table 4). There was a BA $\times$ leaf number interaction in the number of viable seeds per fruit. BA reduced viable seed number in fruit with 1,2 , and 4 leaves but did not affect seed number if more leaves were present. Increasing leaf number per fruit also decreased the number of aborted seeds while increasing the number of viable seeds. There was no effect of leaf number per fruit or BA on total seed number. Soluble solids concentration and fruit weight increased with increasing leaf number.

Fruit growth rate was increased with increasing leaf number per fruit during the first $3 \mathrm{~d}$ after treatment, and the effect was not influenced by BA treatment (Fig. 1A). Fruit growth rate was also increased with increasing leaf number per fruit from 3 to $7 \mathrm{~d}$ after treatment, but low leaf number per fruit dramatically reduced fruit growth rate, regardless of BA application (Fig. 1B and C). BA significantly reduced fruit growth rate on all branches except for that with 32 leaves per fruit.

Between 7 and $19 \mathrm{~d}$ after BA application, increasing leaf number continued to increase fruit growth rate (Fig. 1D, E, and F). BA application decreased fruit growth rate only when leaf number per fruit was one. Most fruit abscission occurred during this period. Fruit growth rate continued to be affected similarly by the number of leaves per fruit between 19 and $35 \mathrm{~d}$ after BA application (Fig. $1 \mathrm{G}$ and $\mathrm{H}$ ). Application of BA appeared to have no additional influence on fruit growth rate during this period.

The response of fruit growth rate to BA application and leaf number per fruit was influenced by maximum air temperature and solar radiation during the first $7 \mathrm{~d}$ after treatment (Fig. 2A and B). Response of fruit growth rate of treatments with 4, 8 or 16 leaves per fruit to BA was similar to that treated with two leaves per fruit. Therefore, only data for treatments with 1,2, and 32 leaves per fruit are presented. Maximum air temperature and solar radiation affected fruit growth rate on all branches, regardless of BA application. BA did not reduce fruit growth rate when the air temperature and solar radiation were low, but it reduced fruit growth rate, especially on branches with less than two leaves per fruit, when the temperature was high.

Fruit size was increased with increasing leaf number per fruit at 12 and $19 \mathrm{~d}$ after treatment (Fig. 3). BA decreased fruit size when leaf number per fruit was one or two, whereas there was no effect of BA on fruit size when leaf number per fruit was more than four at 12 and $19 \mathrm{~d}$ after treatment. At $35 \mathrm{~d}$ after treatment, there was a significant increase in fruit size with increasing leaf number per fruit, especially a dramatic increase from one to eight leaves per fruit.

\section{Discussion}

Apple fruitlet abscission is considered to be the result of competition among fruit, and between fruit and vegetative shoots for essential metabolites, including carbohydrates (Abbott, 1960; Knight, 1980; Quinlan and Preston, 1971). In this investigation, shoot tipping increased fruit retention regardless of BA application (Table 1). BA thinned 'More-Spur McIntosh' apple fruit regardless of whether bourse shoot tips were removed or not, and there was an interaction between BA and shoot tipping. These results can be explained in terms of source-sink relationships. A reduction in fruit drop by shoot tipping is attributed to more photosynthates moving into the fruit (Grauslund, 1978; Quinlan and Preston, 1971), since some sinks (shoot tip) were removed. BA application, which reduced net photosynthesis of apple leaves and reduced carbohydrates available to developing fruit (Yuan and Greene, 2000), promoted fruit abscission even when the shoot tip was removed. Therefore, the combination of BA application, which reduced a source of carbohydrates, and the presence of a shoot tip, which is a strong sink, led to less carbohydrates available to developing fruit and thus the least fruit retention. Although BA application at high rates increases shoot numbers and total growth (Bound et al., 1991; Greene and Autio, 


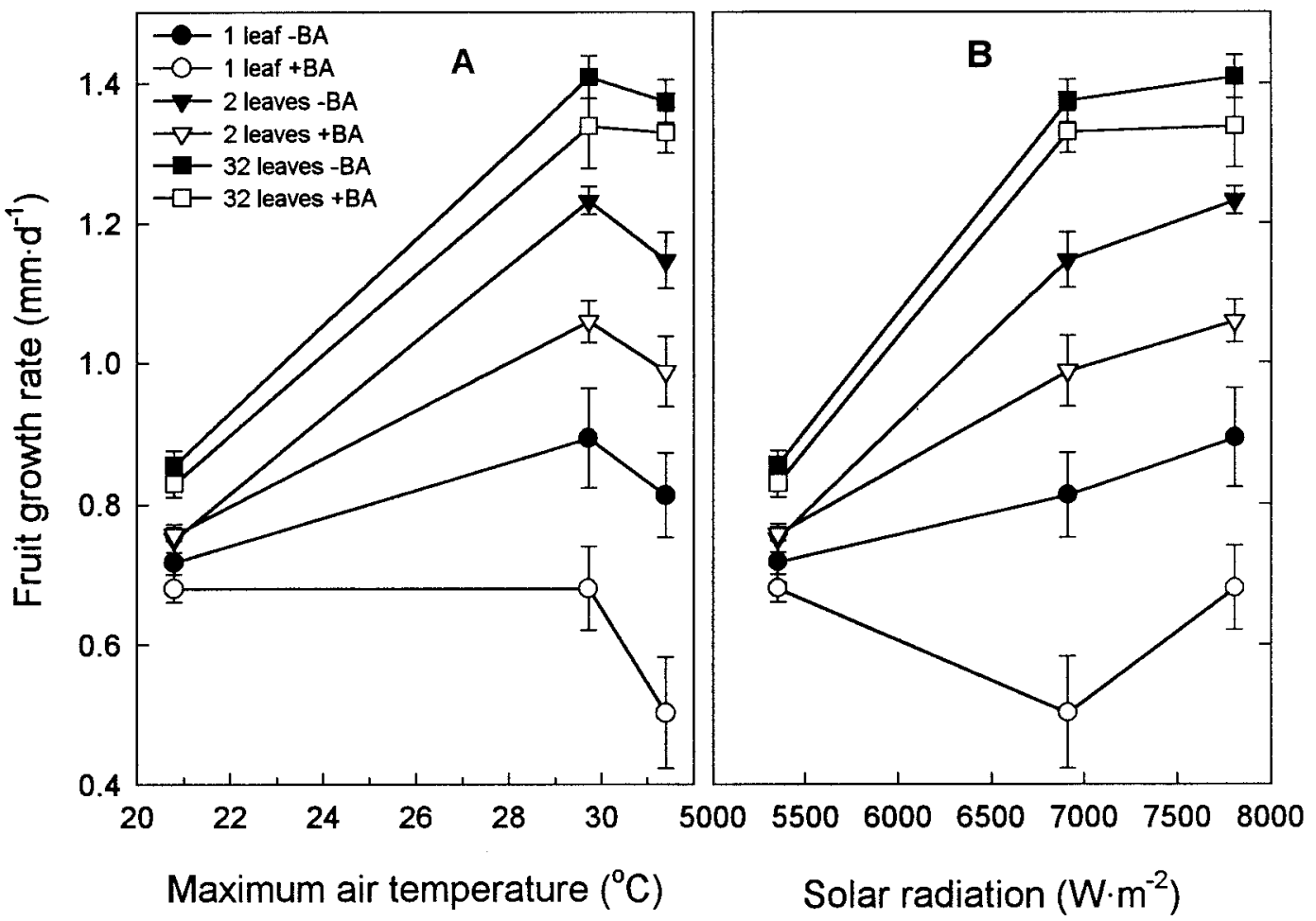

1989), the fact that BA thinned 'More-Spur McIntosh' apple fruit even when the bourse shoot tip was removed, suggests that the mechanism of fruit thinning by BA was not mediated through promoting vegetative growth, at least of the bourse shoot.

Leaf photosynthesis is the main source of carbohydrates for developing fruit. Reduction in leaf area by removal of spur and shoot leaves, which reduces carbohydrates available to young fruit, causes extensive fruit abscission in apples (Arthey and Wilkinson, 1964; Ferree and Palmer, 1982; Llewelyn, 1963, 1968; Proctor and Palmer, 1991; Quinlan and Preston, 1971). Ferree and Palmer (1982) found that final fruit set was reduced by a

Fig. 2. Effects of BA and leaf number on fruit growth rate at different maximum air temperature (A) and solar radiation $(\mathbf{B})$ during the first $7 \mathrm{~d}$ after treatment in 'More-Spur McIntosh' apples (1997). Legend in A applies to B. Data are means $\pm \operatorname{SE}(\mathrm{n}=16)$.

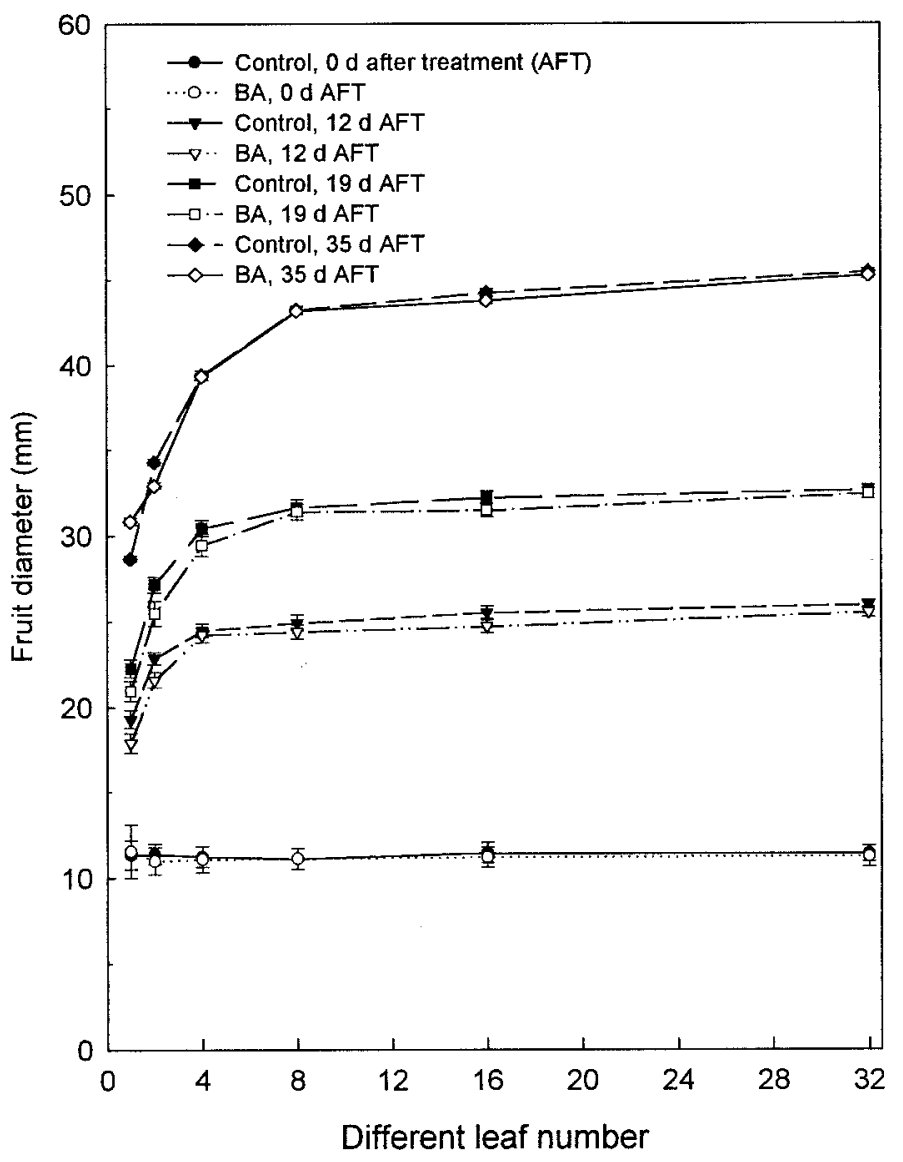

Fig. 3. Effects of BA and leaf number on fruit size of 'More-Spur McIntosh' apples at different dates after treatment. Data are means \pm SE $(n=16)$. combination of ringing and removal of $50 \%$ of spur leaves, whereas a combination of ringing and removal of all spur leaves caused abscission of all fruit. Our results showed that $\approx 25 \%$ of the fruit abscised when spurs were reduced to one fruit and one leaf on girdled small fruiting branches, whereas no fruit abscised when leaf number was two or greater on similar small branches (Tables 2 and 3). This suggests that available carbohydrates were a limiting factor in apple fruit retention during 'June drop', and at least two leaves are required to support a fruit to maturity under the conditions occurring in 1997. BA promoted 'More-Spur McIntosh' apple fruit abscission only when there was one leaf on the girdled fruiting branches, but not when leaf number was two or more (Tables 2 and 3). These results can also be explained in terms of source-sink relationships. Girdling prevented photosynthates from moving away from the girdle to other portions of the tree through phloem, and thus relieved competition that would normally occur from other fruit and growing shoots for carbohydrates and other metabolites. Apparently one leaf almost provided sufficient carbohydrates to meet the threshold demand for one apple fruit on the isolated branch. However, after foliar application of BA, which reduced net photosynthesis of apple leaves by $10 \%$ to $15 \%$ (Yuan and Greene, 2000), we speculate that available carbohydrates were reduced below a threshold level. Therefore, fruit growth rate decreased dramatically and more fruit abscised (Fig. 1). When two or more leaves were present on girdled branches, fruit had sufficient available carbohydrates to meet the threshold demand for continuing growth regardless of BA application.

Leaf area has a strong influence on fruit growth. Fruit growth rate, fruit size and weight increased dramatically with increasing leaf number from one to eight, and then a steady increase thereafter (Figs. 1 and 3, Table 4). Fruit growth rate was decreased by BA application when $<16$ leaves were present on the girdled branches but only from 3 to $7 \mathrm{~d}$ after treatment. However, BA did not influence fruit growth when leaf number was 32 on the girdled branches. These results indicate that carbohydrates and perhaps 
other metabolites were a limiting factor in fruit growth and at least eight leaves were required to support a fruit to grow normally in isolated branches.

The effect of BA on fruit growth rate was influenced by solar radiation and temperature (Fig. 2). BA did not influence fruit growth when the temperature and solar radiation were low, but it reduced fruit growth rate on branches with $<16$ leaves when the temperature was high. This is consistent with results that BA reduced net photosynthesis through increasing dark respiration at high temperature, but not at low temperature. The reduction in net photosynthesis of apple leaves following BA application was sustained for $\approx 6 \mathrm{~d}$ (Yuan and Greene, 2000).

Viable seed number per fruit was increased, whereas aborted seed number was decreased with increasing leaf number per fruit. However, total seed number was not affected (Table 4). BA significantly decreased viable seed number only when $<4$ leaves were present on the girdled branches. These results suggest that the reduced carbohydrate supply by decreasing leaf number and BA application was one of the primary factors causing seed abortion in apples. Similarly, Byers et al. (1991) reported that shading, which decreased photosynthesis and thus reduced the carbohydrates available to the developing fruit, caused seed abortion in 'Redspur Delicious' apple fruitlets.

In conclusion, spur leaf area is negatively associated with thinning efficacy and the number of aborted seeds following BA application. It is most likely that BA thins apple fruit mainly by reducing carbohydrates available to developing fruitlets.

\section{Literature Cited}

Abbott, D.L. 1960. The bourse shoots as a factor in the growth of apple fruits. Ann. Appl. Biol. 48:434-438.

Arthey, V.D. and E.H. Wilkinson. 1964. The effect of pre-blossom defoliation on the cropping of Cox's Orange Pippin apple. Hort. Res. 4:22-26.

Bound, S.A., K.M. Jones, T.B. Koen, and M.J. Oakford. 1991. The thinning effect of benzyladenine on red 'Fuji' apple trees. J. Hort. Sci. 66:789-794.

Byers, R.E., D.H. Carbaugh, C.N. Presley, and T.K. Wolf. 1991. The influence of low light on apple fruit abscission. J. Hort. Sci. 66:7-17.

Elfving, D.C. and R.A. Cline. 1993. Benzyladenine and other chemicals for thinning 'Empire' apple trees. J. Amer. Soc. Hort. Sci. 118:593598.

Ferree, D.C. and J.W. Palmer. 1982. Effect of spur defoliation and ringing during bloom on fruiting, fruit mineral level, and net photosynthesis of 'Golden Delicious' apple. J. Amer. Soc. Hort. Sci. 107:11821186.

Grauslund, J. 1978. Effect of temperature, shoot tipping and carbohydrates on fruit set of apple trees. Acta Hort. 80:207.

Greene, D.W. 1993. A review of the use of benzyladenine (BA) as a chemical thinner for apples. Acta Hort. 329:231-236.

Greene, D.W. and W.R. Autio. 1989. Evaluation of benzyladenine as a chemical thinner on 'McIntosh' apples. J. Amer. Soc. Hort. Sci. 114:68-73.

Greene, D.W., W.R. Autio, and P. Miller. 1990. Thinning activity of benzyladenine on several apple cultivars. J. Amer. Soc. Hort. Sci. 115:394-400.

Greene, D.W., W.R. Autio, J.A. Erf, and Z.Y. Mao. 1992. Mode of action of benzyladenine when used as a chemical thinner on apples. J. Amer. Soc. Hort. Sci. 117:775-779.

Heinicke, A.J. 1917. Factors influencing the abscission of flowers and partially developed fruits of the apple (Pyrus malus L.). Cornell Univ. Agr. Expt. Sta. Bul. 393:1-114.

Knight, J.N. 1980. Fruit thinning of the apple cultivar Cox's Orange Pippin. J. Hort. Sci. 55:267-273.

Llewelyn, F.W.M. 1963. The importance of spur leaves and limesulphur sprays on fruit retention of three apple varieties. Annu. Rept. E. Malling Res. Sta. 1962:89-92.

Llewelyn, F.W.M. 1968. The effect of partial defoliation at different times in the season on fruit drop and shoot growth in Lord Lambourne apple trees. J. Hort. Sci. 43:519-526.

Proctor, J.T.A. and J.W. Palmer. 1991. The role of spur and bourse leaves of three apple cultivars on fruit set and growth and calcium content. J. Hort. Sci. 66:275-282.

Quinlan, J.D. and A.P. Preston. 1971. The influence of shoot competition on fruit retention and cropping of apple trees. J. Hort. Sci. 46:525-534.

Williams, M.W. and L.J. Edgerton. 1981. Fruit thinning of apples and pears with chemicals. U.S. Dept. Agr. Info. Bul. 289.

Wismer, P.T., J.T.A. Proctor, and D.C. Elfving. 1995. Benzyladenine affects cell division and cell size during apple fruit thinning. J. Amer. Hort. Sci. 120:802-807.

Yuan, R. and D.W. Greene. 2000. Benzyladenine as a chemical thinner for 'McIntosh' apples. I. Its fruit thinning effects and associated relationships with photosynthesis, assimilate translocation, and nonstructural carbohydrates. J. Amer. Soc. Hort. Sci. 125(2):169-176. 